https://doi.org/10.30702/ujcvs/19.3505/044061-063

УДК 616.12-07+616.12-089:616.141-007.271-053.2

\title{
Relationship between Clinical Features and Histopathologic Findings in Patients with Pulmonary Vein Stenosis
}

\author{
Mykychak Y ${ }^{1}$, Kozhokar D ${ }^{1}$, Yusifli I. ${ }^{1}$, Yachnik $\mathrm{O}^{1}$, Zakharova V ${ }^{2}$, Yemets I. ${ }^{1}$ \\ ${ }^{1}$ Ukrainian Children's Cardiac Center, Kyiv, Ukraine \\ ${ }^{2}$ National M. M. Amosov Institute of Cardiovascular Surgery of the National Academy of Medical Sciences of Ukraine, \\ Kyiv, Ukraine
}

\begin{abstract}
Pulmonary vein stenosis (PVS) is a rare but serious condition characterized by obstruction of extrapulmonary segments of pulmonary veins which leads to progressive pulmonary hypertension.

Objective. In this study we aimed to determine relationship between clinical features and histopathologic findings in patients with PVS.

Material and methods. We retrospectively reviewed 34 consecutive patients who underwent PV stenosis repair. Surgical wedge biopsy specimens were collected intraoperatively in 11 patients and reviewed using light microscopy.

Results. Affected pulmonary veins in patients with primary PVS were characterized by diffuse stenosis extending into the lung parenchyma. In post-surgical group stenosis was found in a limited segment of pulmonary vein at its ostium. Microscopically, abnormal intimal proliferation was identified in both patient groups. Scaring was predominant finding in patients with post-surgical PVS.

Conclusion. In patients with PVS, pathophysiological mechanism influences the severity and extent of clinical manifestations. A comprehensive understanding of this mechanism may improve results of the treatment.

Keywords: pulmonary vein stenosis, pulmonary hypertension, total anomalous pulmonary venous connection, intimal proliferation.
\end{abstract}

Introduction. Pulmonary vein stenosis (PVS) is a rare but serious condition characterized by obstruction of extrapulmonary segments of pulmonary veins which leads to progressive pulmonary hypertension [1,2]. PVS may occur after total anomalous pulmonary venous connection (TAPVC) repair and affects $10 \%$ to $17 \%$ of these patients $[3,4]$. Less frequently (in $0.4-0.6 \%$ of children with congenital heart disease) PVS presents as a primary congenital disease [5]. Histologically, PVS is characterized by fibrous proliferation within the pulmonary vein walls composed of fibroblasts/ myofibroblasts, which is evident by immunohistochemical expression of smooth muscle actin and muscle-specific actin [6]. Current treatment options for PVS include relief of anatomical obstruction via surgical and transcatheter approaches. Results of these procedures remain suboptimal: PVS-related mortality, pulmonary vein (PV) reintervention and PVS recurrence rates are unacceptably high both for primary $^{7}$ and postoperative PVS [8].

Objective. In this study we aimed to determine relationship between clinical features and histopathologic findings in patients with PVS.

Materials and methods. We retrospectively reviewed 34 consecutive patients who underwent PV stenosis repair at the Ukrainian Children's Cardiac Center, Kyiv, from January 2010 to March 2019. Surgical wedge biopsy specimens were collected intraoperatively in 11 patients.
Archived slides were reviewed using light microscopy in all cases.

Results. The study group consisted of 7 patients with primary PVS and 4 patients with PVS after TAPVC repair. Diagnosis of PVS was established by two-dimensional and Doppler echocardiographic studies of each pulmonary vein. Computed tomography (CT) was performed in 9 of 11 patients (except 2 patients with primary PVS) to provide better assessment of the PV upstream. In patients with primary PVS, affected pulmonary veins were diffusely stenotic, with stenosis extending into the lung parenchyma, i.e. "upstream" stenosis [11]. Among these patients, bilateral disease was present in 4 cases. Also, patients with primary PVS were characterized by progressively worsening obstruction. We observed a patient who died within one month after primary PVS repair: autopsy showed that all PVs became occluded along their length even after successful surgical relief confirmed at discharge.

In post-surgical group the extent of stenosis was mostly limited to the ostial segment of pulmonary veins.

Histological findings. Macroscopically, specimens consisted of pulmonary vein wall fragments adjacent to the left atrium, fibrous tissue from the vein lumen and occasional complete cross-sections. Microscopically, abnormal intimal proliferation and duplication of inner elastic membrane were identified, which led to the lumen obstruction in 


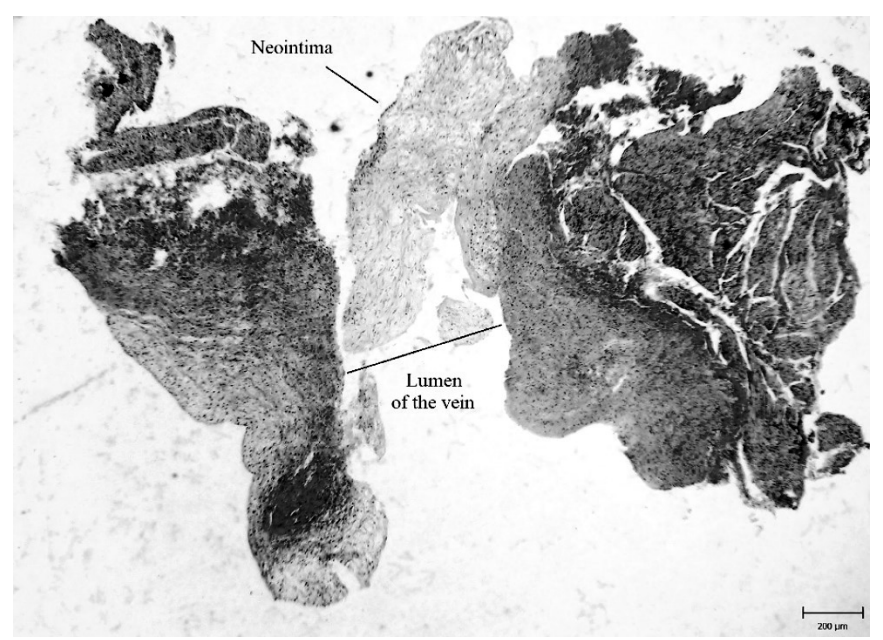

Fig. 1. Obstruction of the pulmonary vein caused by abnormal intimal proliferation in a patient with primary PVS. Van Gieson's stain, $x 40$

stenotic pulmonary veins (Fig. 1) in both groups of patients. Meanwhile, in specimens obtained from post-surgical patients, scaring was predominant finding. Typical fibromyxoid intimal thickening was absent in only one specimen obtained from post-surgical patient. Heavily collagenized scarring at the site of direct veno-atrial anastomosis (Fig. 2) caused luminal obstruction in this case. This patient subsequently underwent a series of repeated balloon angioplasties described previously [12].

Discussion. We studied and compared clinical features and histopathologic findings in patients with PVS. We found that patients with primary PVS are characterized by diffuse stenosis of pulmonary veins extending to the vessels of intraparenchymal segment, while in post-surgical group stenosis was mostly limited to an ostial segment of pulmonary vein. Microscopical examination revealed that specimens obtained from the patients from both primary and postsurgical PVS group had fibromyxoid intimal thickening, typical for this lesion, although in post-surgical PVS scaring was predominant finding. Thus, we identified correlation between clinical manifestation and histological findings in patients with PVS.

Surgical repair or transcatheter intervention is the main current therapeutic strategy, with results being, however, quite disappointing. The novel treatment should be targeted at pathophysiological mechanism. Ongoing medical treatment research is aimed at different pathogenetic mechanisms of PVS [9]. Callahan et al. [10], Kato H et al. [11] have shown that activation of tyrosine kinase and angiotensin II pathways leads to PVS. Currently, there are 3 registered clinical trials related to PVS treatment. In two trials tyrosine-kinase pathway was targeted using known chemotherapeutic agents. The third trial studies losartan as an agent to reduce neointimal formation by blocking TGF-

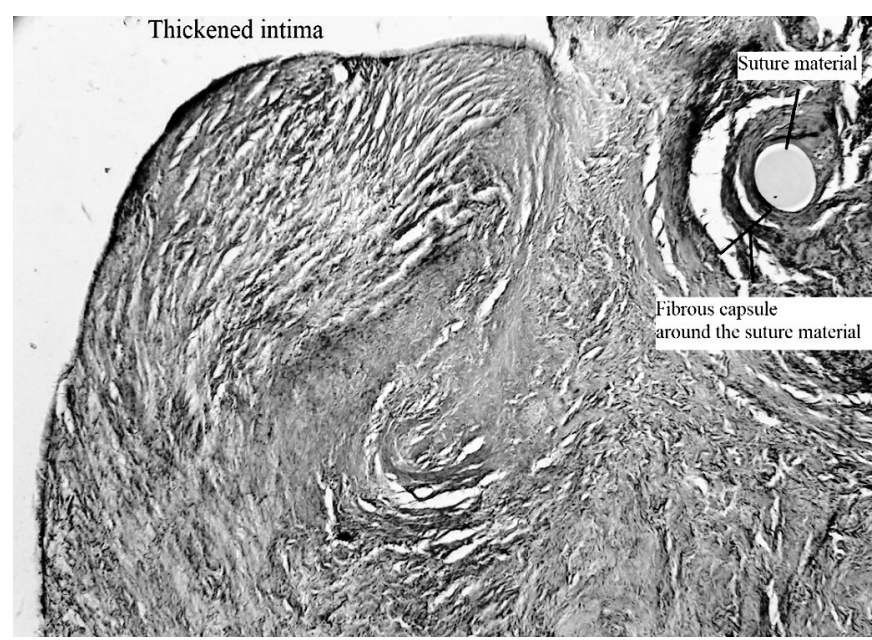

Fig. 2. Specimen obtained of a patient with post-surgical PVS with heavily collagenized scarring in site of surgical manipulation. Hematoxylin and eosin stain, $x 400$

$\mathrm{B}$ and angiotensin II mediated endothelial to mesenchymal transition.

In our study we have identified typical histological findings characteristic for each of PVS subtypes. They reflect pathogenetic mechanism and influence further outcomes such as mortality and recurrence rates. Firbointimal proliferation is the main cause of disease progression and recurrence of PVS.

Conclusion. Certain pathophysiological mechanisms have been shown to influence the severity of clinical manifestation in different types of PVS. A comprehensive understanding of these mechanisms may improve results of the treatment.

\section{References}

1. Bernstein J, Noke AC, Reed JO. Extrapulmonic stenosis of the pulmonary veins. Circulation. 1959;19:891-7.

2. Kovach AE, Magcalas PM, Ireland $\mathrm{C}$, McEnany $\mathrm{K}$, Oliveira AM, Kieran MW, et al. Paucicellular Fibrointimal Proliferation Characterizes Pediatric Pulmonary Vein Stenosis: Clinicopathologic Analysis of 213 Samples From 97 Patients. Am J Surg Pathol. 2017 Sep;41(9):1198-204.

3. Caldarone CA, Najm HK, Kadletz M, Smallhorn JF, Freedom RM, Williams WG, et al. Relentless pulmonary vein stenosis after repair of total anomalous pulmonary venous drainage. Ann Thorac Surg. 1998;66:1514-20.

4. Seale AN, Uemura H, Webber SA, Partridge J, Roughton M, Ho SY, et al. Total anomalous pulmonary venous connection: morphology and outcome from an international population-based study. Circulation. 2010;122:2718-26.

5. Viola N, Alghamdi AA, Perrin DG, Wilson GJ, Coles JG, Caldarone CA. Primary pulmonary vein stenosis: the impact of sutureless repair on survival. J Thorac Cardiovasc Surg. $\quad 2011 ; 142: 344-50 . \quad$ https://doi.org/10.1016/j. jtcvs.2010.12.004 
6. Riedlinger WFJ, Juraszek AL, Jenkins KJ, Nugent AW, Balasubramanian S, Calicchio ML, et al. Pulmonary vein stenosis: expression of receptor tyrosine kinases by lesional cells. Cardiovasc Pathol. 2006;15:91-9. https://doi. org/10.1016/j.carpath.2005.11.006

7. Kalfa D, Belli E, Bacha E, , Lambert V, di Carlo D, Kostolny M, et al. Primary Pulmonary Vein Stenosis: Outcomes, Risk Factors, and Severity Score in a Multicentric Study. Ann Thorac Surg. 2017 Jul;104(1):182-9. https://doi. org/10.1016/j.athoracsur.2017.03.022

8. Kalfa D, Belli E, Bacha E, Lambert V, di Carlo D, Kostolny M, et al. Outcomes and Prognostic Factors for PostSurgical Pulmonary Vein Stenosis in the Current Era. J Thorac Cardiovasc Surg. 2018 Jul;156(1):278-86. https:// doi.org/10.1016/j.jtcvs.2018.02.038

9. Rehman M, Jenkins KJ, Juraszek AL, Connor JA, Gauvreau K, Muneeb M, et al. A Prospective Phase II
Trial of Vinblastine and Methotrexate in Multivessel Intraluminal Pulmonary Vein Stenosis in Infants and Children. Congenit Heart Dis. 2011;6(6):608-23. https:// doi.org/10.1111/j.1747-0803.2011.00574.x

10. CallahanR, Kieran M, Baird C, Colan S, Gauvreau K, Ireland $\mathrm{C}$, et al. Adjunct targeted biological inhibition agents to treat aggressive multi-vessel intraluminal pediatric pulmonary vein stenosis. J Pediatr. 2018;198:29-35.

11. Kato H, Fu YY, Zhu J, Wang L, Aafaqi S, Rahkonen O, et al. Pulmonary vein stenosis and the pathophysiology of «upstream» pulmonary veins. J Thorac Cardiovasc Surg. 2014 Jul;148(1):245-53.

12. Mykychak Y. Complex treatment of recurrent pulmonary vein stenosis. Herald Cardiovascular Surgery. 2018 Nov;4(33):94-6.

\title{
Взаємозв’язок між гістопатологічними змінами та клінічними проявами в пацієнтів зі стенозом легеневих вен
}

\author{
Микичак Я. Б. ${ }^{1}$ Кожокар Д. М. ${ }^{1}$, Юсіфлі І. Б. ${ }^{1}$, Ячнік О. Ф. ${ }^{1}$, Захарова В. П. ${ }^{2}$, Ємець І. М. ${ }^{1}$
}

${ }^{1}$ ДУ «Науково-практичний медичний центр дитячої кардіології та кардіохірургії МОЗ України», м. Київ, Україна

${ }^{2}$ ДУ «Національний інститут серцево-судинної хірургії імені М. М. Амосова НАМН України», м. Київ, Україна

Резюме. Стеноз легеневих вен (СЛВ) - це рідкісне прогресуюче захворювання легеневих вен. Класифікація СЛВ утруднена досить частим поєднанням з іншим вадами, складними механізмами розвитку. Загалом виділяють дві клінічні категорії стенозу: первинний і вторинний. Первинний, або вроджений, стеноз спостерігається в дітей з нормальним з'єднанням легеневих вен і без оперативних втручань на серці в анамнезі. Вторинний, або постхірургічний, - після хірургічного лікування вроджених вад серця, здебільшого після корекції тотального аномального дренажу легеневих вен. Основними методами діагностики є ультразвукове дослідження серця та комп’ютерна томографія. Гістологічно СЛВ характеризується фіброзною проліферацією інтими екстрапульмональних легеневих вен. В основі проліферації лежить ендотеліально-мезенхімальна трансформація (ЕМТ). В останні роки активно ведуться дослідження для визначення механізму СЛВ й ефективності нових методів лікування, а саме хіміотерапії, так як хірургічна корекція та інші методи лікування мають високий рівень рестенозування, повторних втручань і смертності.

Мета роботи. Метою цього дослідження є виявлення зв'язку між клінічними особливостями та гістопатологічними змінами в пацієнтів зі стенозом легеневих вен.

Матеріали і методи. Ми ретроспективно розглянули 34 пацієнтів, прооперованих з приводу СЛВ. В 11 пацієнтів інтраопераційно були взяті зразки хірургічного біоптату та розглянуті за допомогою світлової мікроскопії.

Результати. У хворих з первинним СЛВ уражені легеневі вени характеризувались дифузним стенозом з поширенням у паренхіму легенів. У постхірургічній групі стеноз був виявлений в обмеженому сегменті легеневої вени, біля устя. При мікроскопічному дослідженні в обох групах виявлено типову для СЛВ фіброміксоїдну неоінтимальну проліферацію. Проте у хворих з післяопераційним СЛВ формування рубцевої тканини було домінуючою знахідкою.

Висновок. У пацієнтів із СЛВ патофізіологічний механізм впливає на характер і вираженість клінічних проявів. Усебічне розуміння цього механізму може поліпшити результати лікування.

Ключові слова: стеноз легеневих вен, легенева гіпертензія, тотальний аномальний дренаж легеневих вен, інтимальна проліферація.

Стаття надійшла в редакцію 17.04.2019 p. 